\title{
Modular Multifunctional Protein Vectors for Gene Therapy
}

\author{
Hugo Peluffo \\ Department of Histology and Embryology, Faculty of Medicine, University of the Republic \\ (UDELAR) and Neurodegeneration Laboratory, Institut Pasteur de Montevideo
}

Uruguay

\section{Introduction}

The introduction of genes into the organism or the regulation of the expression of endogenous genes has emerged in the last decade as a very potent strategy for correcting monogenic inherited diseases, treating acute disorders, and slowing down the progression of diseases without known cure. In addition it constitutes an important tool for research, which has been widely used and has contributed to show the mechanisms behind several physiological processes and pathologies.

Adequate carriers able to transfer DNA or RNA into target cells have been largely explored. However, this is an area under continuous expansion as there is no ideal vector suitable for all applications. In fact, no individual vector will meet all the characteristics for a perfect or ideal vector, as many of the needs are different and even contradictory. For example, immunogenicity is in most cases an undesirable side effect, while it is a valuable property when treating tumours as it contributes to their clearance. Another example of contradictory needs of one single vector would be the capacity of a vector to determine the overexpression of the transgenic protein for life. This would be an essential property for the treatment of inherited diseases produced by the lack of a particular protein, however for the treatment of acute injuries the lifelong expression of a therapeutic protein will probably be deleterious. Moreover, some vectors do not transduce post-mitotic cells like neurons or muscle fibres, which is a drawback for targeting these cell types but may be an advantage for the targeting of cancer cells. Thus, there is a need for diverse type of vectors for diverse therapeutic or experimental paradigms, and in particular versatile tuneable vectors would be very interesting. Moreover, several basic problems with the known vectors persist, like toxicity, oncogenicity, immunogenicity, low transfection efficiency, or poor bioavailability, which need further consideration and efforts.

Due to their natural efficiency, viruses have been modified to act as vectors, and they have shown a good degree of success. Non-viral vectors have also been developed by combining several properties necessary for transfection: nucleic acid attachment and condensation, cell attachment, cell entry, endosomal escape, intracellular trafficking, nuclear entry, and nucleic acid release. Some of these vectors are quite simple, as the ones formed by the combination of nucleic acids and lipid components or other carriers like polyethylene glycol (PEG). Others include the previous components but have in addition attached targeting molecules like antibodies, enabling these vectors to preferentially transfect a given tissue. In fact even 
magnetic fields have been used to concentrate suitable engineered vectors to a given area (Corchero and Villaverde 2009).

An interesting type of non-viral vectors is the one based on multifunctional proteins (Aris and Villaverde 2004; Mastrobattista et al. 2006). The combination of functional domains in a single polypeptide is a simple yet powerful approach for the development of vectors suitable for gene therapy. In fact, this approach has generated the first prototypes of modular protein gene therapy vectors. Three general methods have been used for the engineering of these molecules: i) production of a recombinant protein by the direct fusion of the functional domains; ii) production of a recombinant protein by combining a known scaffold protein and several functional domains inserted into exposed regions of the scaffold protein; and iii) chemical conjugation of functional domains and proteins. Many of these vectors can be produced recombinantly, generating reproducible and stable stocks appropriate for the formulation of clinically usable drugs. Moreover, the modular nature of these versatile vectors enables the combination of different domains to fulfil the changing requirements of pathological end experimental situations.

\section{Functional domains available}

\subsection{Nucleic acid attachment and condensation}

Trans-membrane transport of DNA is an inefficient process, and thus the successful introduction of a transgene into a target cell must include two important steps regarding the plasmid or oligonucleotid DNA that is included in the vector. First, the extended DNA needs to be condensed into an ordered compact nano-particle, and second, once inside the nucleus, the DNA must be de-condensed and thus accessible to transcription. Basic peptides or polycations have been exploited for the interaction with the DNA backbone due to their electrostatic interactions (Bloomfield 1996; Saccardo et al. 2009)(see Table 1). When DNA is mixed with these condensing agents, smaller molecules of different shapes are formed mainly depending on DNA size (Vijayanathan et al. 2002). For instance, in the absence of DNA, the HNRK modular vector that uses poly-lysine for DNA condensation, self-organize as amorphous, polydisperse particulate entities ranging from a few nanometres up to around one micron. However, in the presence of DNA, protein-DNA complexes appear as tight and rather monodisperse spherical-like nanoparticles of around $80 \mathrm{~nm}$ in diameter (Domingo-Espín et al. 2011). The most widely used condensing agent is a poly-lysine chain (Saccardo et al. 2009). Poly-lysine polymers containing at least 6 lysines will efficiently condense DNA, however, additional 4 to 9 lysines are needed to fully condensate the DNA into smaller particles of $50-100 \mathrm{~nm}$, increasing in this way many folds the transfection capacity (Wadhwa et al. 1997). Other basic peptides used are the poly-arginine peptides, which not only induce DNA condensation, but also show membrane translocation potential (Futaki et al. 2001) and nuclear translocation capacity, determining in this way transgene expression (Kim et al. 2003; Vazquez et al.).

The condensed DNA by these peptides is partially protected from cellular acid nucleases of the lysosomal compartment (Krishnamoorthy et al. 2003; Ross et al. 1998; Wolfert and Seymour 1998) and serum nucleases, inducing an extended half-life in serum (Kumar et al. 2007) and in the circulation, making tissue targeting possible (Kawabata et al. 1995; Nishikawa et al. 2000a). For example, the addition of the acid nuclease inhibitor DMI-2 induced a 10-fold increase in receptor-mediated transfection in cultured cells exposed to a 
Surfactant Protein A-poly-lysine modular vector or a transferrin-poly-lysine modular vector (Ross et al. 1998). Naturally DNA condensing proteins have also been used for the construction of modular vectors. For instance, Histones condense plasmid DNA and protects it from endonucleases, being the lysine-rich $\mathrm{H} 1$ Histone the most effective one (Pyhtila et al. 1976). Moreover, some nuclear localization signals like the NLS peptide from SV40 virus large T-antigen are lysine-rich peptides that when used as a tetramer can efficiently condense DNA without loosing its nuclear localization properties (Ritter et al. 2003).

\subsection{Cell attachment and cell targeting}

When a viral or non-viral gene therapy vector is injected intravenously, most of the vectors will localize mainly in the liver but also in the kidneys, lungs and spleen. While this is normally a problem to circumvent for most gene therapy applications, it constitutes an advantage for the expression of molecules in the liver. There are many fetal metabolic diseases resulting from a defect or a deficiency of hepatocyte-derived proteins. Moreover, the liver can be considered as a platform to produce various proteins secreted into the blood. Therefore, many pioneer studies focused on the development of more efficient gene delivery systems for the introduction of therapeutic genes selectively into hepatocytes $(\mathrm{Wu}$ and $\mathrm{Wu}$ 1988). Intravenously injected plasmids are cleared from the circulation by the liver non-parenchymal cells by a scavenging receptor mediated mechanism (Kawabata et al. 1995). When Nishikawa and colleagues administered naked 32PDNA into the tail vein of mice, about $40 \%$ and $10 \%$ of the radioactivity rapidly accumulated in the liver and kidneys, respectively (Nishikawa et al. 2000b). Again, the main cell-types targeted were the liver nonparenchymal cells: Kupffer cells and endothelial cells. When they injected a vector composed of 32PDNA/polyornithine, little effect on the distribution of the DNA was observed. However, the injection of the 32PDNA/Gal-pOrn galactose-mediated hepatocytetargeting vector induced a $60 \%$ hepatic accumulation of radioactivity, but more interestingly, most of the targeted cells were now hepatocytes instead of Kupffer or endothelial cells. The same effect was observed at the level of luciferase transgene expression, indicating that the DNA/Gal-pOrn vector was not only able to adhere and enter preferentially into hepatocytes, but it could also transfect them.

Many different domains of known proteins and sugars have been used for cell targeting of modular vectors, like galactose (Wu and Wu 1987), transferrin (Wagner et al. 1990), foot-andmouth disease virus integrin interacting peptide (Aris et al. 2000; Aris and Villaverde 2003; Domingo-Espín et al. 2011), nerve growth factor (Ma et al. 2004; Zeng et al. 2004), surfactant protein A (Ross et al. 1995), rabies virus glycoprotein (Kumar et al. 2007), tetanus toxin fragment Hc (Box et al. 2003; Knight et al. 1999), cholera toxin b chain (Barrett et al. 2004), and neurotensin (Navarro-Quiroga et al. 2002). In an interesting study, Arango-Rodríguez and colleagues showed that they could target only substantia nigra neurotensin high affinity receptor positive neurons by means of a modular vector that displayed neurotensin, while no other neurons were transfected (Arango-Rodriguez et al. 2006). In vivo, many of these targeting systems have shown success (see Table 1). An additional interesting targeting strategy is the use of antibodies (Berhanu and Rush 2008; Buschle et al. 1995; Thurnher et al. 1994). For instance, the use of the 1E3 antibody against the Tn antigen expressed on many carcinomas coupled to polylysine induced an important increase in the transfection of a cancer cell line (Thurnher et al. 1994). Another vector, named fkAbp75-ipr, possess several 


\begin{tabular}{|c|c|c|c|c|c|c|c|c|c|}
\hline 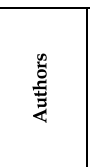 & 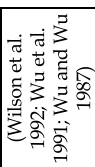 & 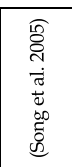 & 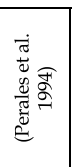 & 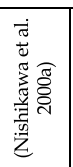 & 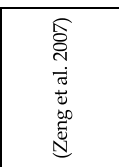 & 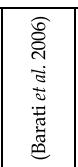 & 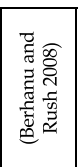 & 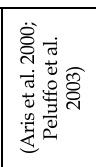 & 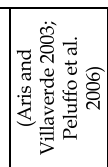 \\
\hline 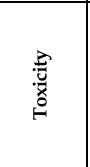 & 之 & 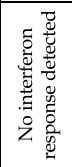 & 之 & 之 & $z$ & 之 & 之 & z & 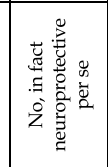 \\
\hline 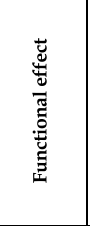 & 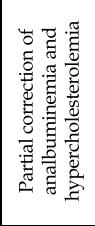 & 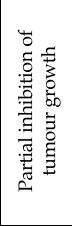 & 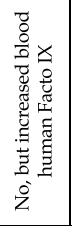 & 之 & 令 & 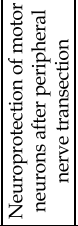 & 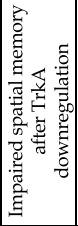 & 会 & 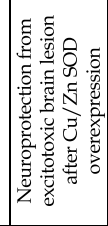 \\
\hline 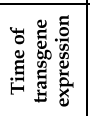 & 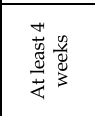 & 之 & 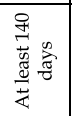 & 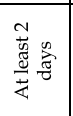 & 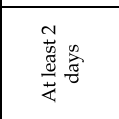 & 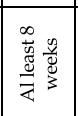 & $\begin{array}{l}\text { ñ } \\
\text { त्ञ } \\
\text { ते }\end{array}$ & 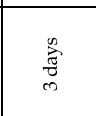 & 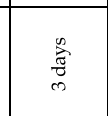 \\
\hline 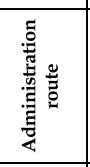 & $\doteq$ & 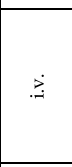 & $\stackrel{.}{.}$ & $\therefore$ & 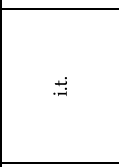 & 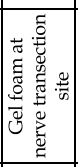 & 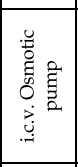 & نب. & \\
\hline 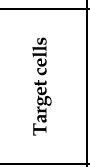 & 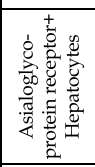 & 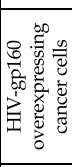 & 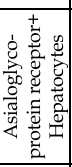 & 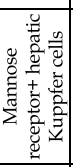 & 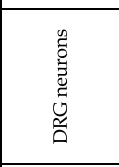 & 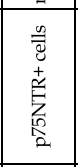 & 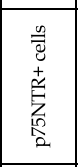 & 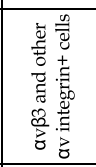 & 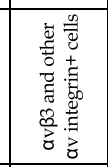 \\
\hline రัّ & 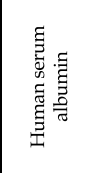 & 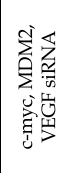 & 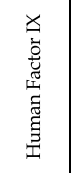 & 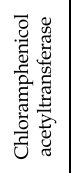 & 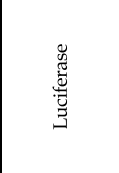 & $\begin{array}{l}\text { 岂 } \\
\text { Ô. }\end{array}$ & 莺 & 获 & 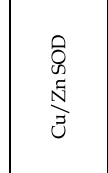 \\
\hline 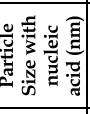 & 之 & 合 & 궁 & สి & $\begin{array}{l}10 \\
10 \\
0 \\
+1 \\
0 \\
0 \\
0\end{array}$ & z & 会 & 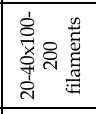 & 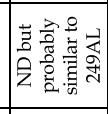 \\
\hline 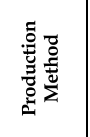 & 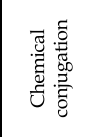 & 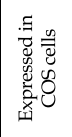 & 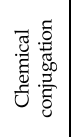 & 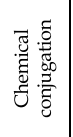 & 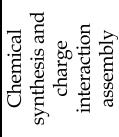 & 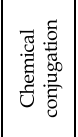 & 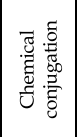 & 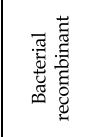 & 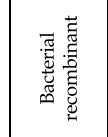 \\
\hline 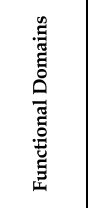 & 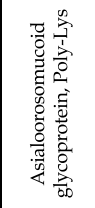 & 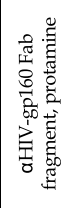 & 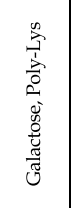 & 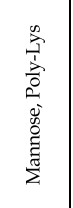 & 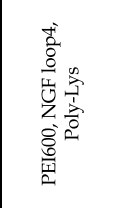 & 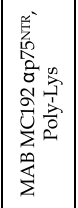 & 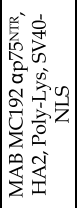 & 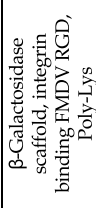 & 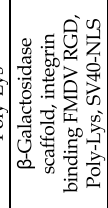 \\
\hline 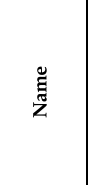 & $\begin{array}{l}\text { 噜 } \\
\text { \& }\end{array}$ & 空 & $\begin{array}{l}\overrightarrow{\mathrm{c}} \\
\text { 离 }\end{array}$ & 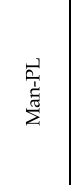 & 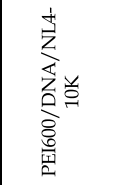 & 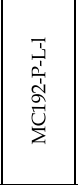 & 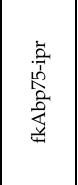 & $\begin{array}{l}\text { 扸 } \\
\text { वे }\end{array}$ & $\begin{array}{l}\text { 岕 } \\
\text { 竞 }\end{array}$ \\
\hline
\end{tabular}




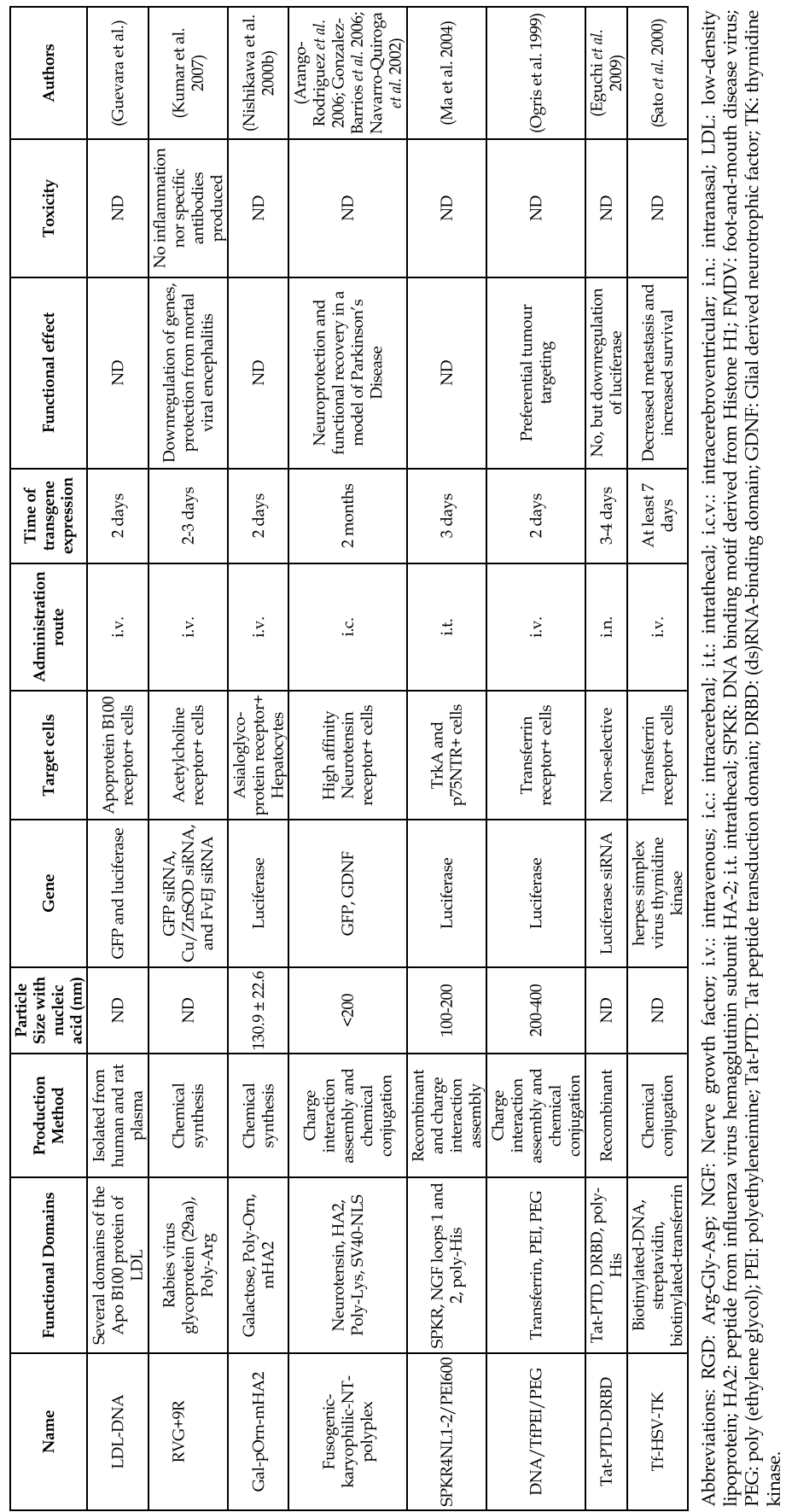

Table 1. Modular protein vectors effective in vivo 
functional domains (see Table 1), being one of them the monoclonal antibody MC192 against p75NTR, the low affinity neurotrophin receptor (Berhanu and Rush 2008). By injecting it intracerebroventricularly coupled to siRNA against TrkA, one of the high affinity neurotrophin receptors, Berhanu and Rush were able to down-regulate TrkA expression in p75NTR expressing cells and correlate this with functional alterations like impaired spatial memory.

\subsection{Endosomal escape}

A limiting step for receptor-mediated gene delivery is the escape from endosomes, as the vector needs to gain access to the cytosol to enter the nuclei. Fusogenic peptides are reported to strongly enhance in vitro gene transfer after being incorporated into carrier systems by chemical linkage (Box et al. 2003; Fisher and Wilson 1997; Navarro-Quiroga et al. 2002; Nishikawa et al. 2000b; Ogris et al. 2001; Wagner et al. 1992) or by ionic interaction (Gottschalk et al. 1996; Plank et al. 1994), but co-treatment of the cells with the vector and the fusogenic peptide may also be effective (Read et al. 2005). The most widely used method for endosome escape is based on the amino-terminal motif of influenza virus hemagglutinin subunit HA2 (Plank et al. 1994; Wagner et al. 1992). For example, Nishikawa and colleagues showed that when an acid-sensitive fusogenic peptide derived from HA2 was incubated with mouse erythrocytes at $\mathrm{pH} 5.0$, it induced hemolysis while it did not show any significant hemolytic activity at $\mathrm{pH} 7.4$ (Nishikawa et al. 2000b). Interestingly, the same study showed that the in vivo liver transgene expression obtained after intravenous injection of the vector DNA/Gal-pOrn-mHA2 was 300 fold higher than that obtained with the same vector lacking the HA2 domain (Nishikawa et al. 2000b).

Other domains used for DNA condensation or vector purification as polylysine or polyhistidine have shown endosome disrupting activities (Read et al. 2005; Zauner et al. 1997). The most effective ones were histidine rich polyplexes formed by the condensation of approximately 50 monomers of Cys-His ${ }_{6}-\mathrm{Lys}_{3}-\mathrm{His}_{6}-\mathrm{Cys}$ and DNA (Read et al. 2005). In this study, the endosomolytic agent chloroquine, which normally enhance the transfection capacity of most non-viral vectors, did not enhance the transfection with the histidine rich polyplexes while it enhanced transfection with other non-viral vectors, suggesting that the poly-his domains are in fact endosomolytic. Though polycations like polylysine may be toxic to cells, especially if they have membrane-disrupting activity, this polyhistidine vector showed no toxicity. Histidine becomes positively charged when the $\mathrm{pH}$ decrease to less than 7 and thus becomes useful for the permeabilization of the endosomal membrane induced by acidification of endosomes, increasing cell transfection (Midoux et al. 1998). In vivo, many of these endosomal escape systems have shown success (see Table 1). For an extensive review on different strategies and domains used for endosomal escape please refer to FerrerMiralles et al. (Ferrer-Miralles et al. 2008).

For the introduction of siRNA and DNA into cells, several cationic peptide transduction domains or also called cell-penetrating domains have been used. TAT, 8xArg, Hph-1or Antp domains can deliver a wide variety of cargo into primary cells, to most tissues, and are in addition being evaluated in clinical trials (Gump and Dowdy 2007). For instance, when the Tat-domain was combined with a poly-His domain and the (ds)RNA-binding domain DRBD, the vector coupled to siRNA could successfully down-regulate Luciferase expression in the nasal and tracheal passages for 4 days after intranasal administration (Eguchi et al. 2009). An important characteristic of these systems using cell-penetrating peptides is that they are not cell-specific, and thus should be used for general non-selective transfection. A 
careful evaluation of the toxicity of this cell penetrating domains in in vivo settings has to be performed as toxicity of Tat protein has been reported (Cardozo et al. 2007), specially for the CNS (Bonavia et al. 2001; Nath et al. 1996). In addition, toxicity of the Antp domain has also been reported for many cell types (Cardozo et al. 2007).

\subsection{Nuclear translocation}

The transgene expression levels obtained after plasmid DNA injection into the cytoplasm or the nucleus showed that de nuclear double membrane and its pores are important barriers for naked DNA (Liu et al. 2003; Pollard et al. 1998). The selection of macromolecules that will be actively imported into the nucleus occurs at the nuclear pore complex, which is composed of more than 50 different proteins. The pore complex will recognise importin proteins bound to short (normally 4-8 amino acids) nuclear localization signals which can be located almost anywhere in the amino acid sequence of the protein, and which are rich in the positively charged amino acids lysine and arginine and usually contains proline (Pouton 1998). This mechanism has been exploited for the design of modular protein vectors, introducing nuclear localization sequences like the SV40 NLS peptide from the T antigen (Aris and Villaverde 2003; Fritz et al. 1996). For instance, Aris and co-workers introduced this nuclear localization sequence into the 249AL modular vector (see Table 1) and they observed an enhanced transgene expression with the resulting vector termed NLSCt (Aris and Villaverde 2003). However, studies performed in cells in culture show that even in the presence of nuclear localizations sequences, complexes of more than $60 \mathrm{~nm}$ seem to be excluded (Chan et al. 2000). This data are in contrast to the high transfection efficiency obtained, even in vivo, with different modular protein vectors that exceeds this size, reaching 200nm (see Table 1). One can speculate that in fact some molecules of up to $200 \mathrm{~nm}$ can be imported into the nucleus by being flexible, or that during the interaction of the vector with the nuclear import machinery the vector is disassembled and only the DNA is imported.

Another important step for efficient transgene expression may be the release of the nucleic acid from the vector once in the nucleus. Several studies have addressed the possible enhancement of the release of the DNA by the cellular reducing conditions. For example, histidine rich polyplexes were able to release the complexed DNA when exposed to the reducing agent Dithiothreitol (DTT), suggesting that in cells a similar mechanism would occur (Read et al. 2005). In fact, the increase in the cellular antioxidant and reducing agent glutathione, induced an important 200 fold increase in the transfection observed with the histidine rich polyplexes, but only a 3fold increase was observed with the PEI/DNA vector, another non-viral vector with no reduction-dependent release of DNA. Though this is an interesting phenomenon, it is difficult to understand why the cytosol reducing conditions do not disassemble the vector too early, determining that the DNA is released into the cytosol instead of inside the nucleus, not favouring the transfection process.

\subsection{Trophic vectors/functional vectors}

An attractive possibility is the combination of the effects mediated by the overexpression of a transgene and the direct effects of the vector per se. In fact, as modular vectors normally take advantage of a cell attaching motif for receptor mediated endocytosis, they tend to display intrinsic activities. More importantly, the use of trophic factors or toxin domains for cell attachment and internalization is ideal, as their natural mechanism of action includes the attachment to high affinity cell surface receptors, the endocytosis to early endosomes, 
and even being transported to the cell soma in the case of neurons (Lalli and Schiavo 2002). An interesting modular vector was produced combining a polylysine tail with the loop 4 of the nerve growth factor (NGF) (Zeng et al. 2004; Zeng and Wang 2005). This "trophic vector" maintained the trophic effects of NGF, was able to condensate DNA, and when combined with polyethylenimine (PEI600), transfected cells in culture that expressed NGF receptors but not cells without these receptors. Interestingly, the DNA-PEI600 showed a size of $445 \mathrm{~nm}$ and an zeta potential of $6,2 \mathrm{mV}$, but the addition of the NGF loop4 poly-lysine peptide to the complex induced the formation of smaller $180 \mathrm{~nm}$ particles with a zeta potential of $23,2 \mathrm{mV}$ (Zeng et al. 2007). This shows that the addition of targeting peptides to non-specific DNA/condensing products complexes may in fact contribute to enhance not only the targeted delivery but also to decrease the particle size and charge of the resulting vector. A somehow more complex trophic vector including NGF loops was also produced. It combined the loops 1 and 2 of NGF and the SPKR4 domain derived from histone H1 DNA binding motif, linked together by a $\alpha$-helical linker (Ma et al. 2004). Both NGF-loop derived vectors could even transfer a transgene in vivo preferentially to dorsal root ganglia neurons (which express NGF receptors) after intrathecal spinal cord injection (Ma et al. 2004; Zeng et al. 2007). Several toxins have been used as cell attachment motifs (Andreu et al. 2008; Box et al. 2003; Knight et al. 1999), and some motifs of these toxins can in fact display trophic effects (Chaib-Oukadour et al. 2004), and have thus been used to design trophic vectors.

An important consideration regarding many acute injuries is that the therapeutic time window is short. In those cases, a direct trophic or functional effect of the vector per se could extend the therapeutic window, giving time for the transgene to be expressed and mediate its own effects. For example, the neuroprotection observed after an acute brain injury using the vector termed NLSCt was partially mediated by the transgene overexpressed, but also partially mediated by the RGD integrin-interacting motif of the vector itself (Peluffo et al. 2006; Peluffo et al. 2007). In this experimental setting the direct injection of the vector into the lesioned brain area was performed 4 hours after the lesion. The CNS is a tissue that tolerates injures very badly due to its high dependence on blood flow and oxygen consumption, and its poor regeneration capacity. This determines that the therapeutic window for the treatment of acute injuries is very short. Interestingly, even in this experimental paradigm, the modular recombinant NLSCt vector overexpressing the anti-oxidant enzyme $\mathrm{Cu} / \mathrm{Zn}$ superoxide dismutase (SOD) could mediate neuroprotection (Peluffo et al. 2006). These studies shows the wide possibilities of combining the vectors themselves with active protein domains like trophic factors, which will exert rapid direct effects, which in turn may increase the therapeutic window or the potency of the effect of the transgene used.

\section{Immunogenicity and inflammation}

The introduction of modular protein vectors into the organism may be accompanied by a humoral or cell-mediated immune response against the inserted motifs, which in many cases are derived from viral molecules. However, when injected intravenously, the Rabies virus glycoprotein (29aa)-Poly-Arg vector (RVG-9R) (see Table 1) did not induce an antibody response or an increase in several pro-inflammatory cytokines evaluated (Kumar et al. 2007). In another example, when the recombinant 249AL vector (see Table 1) was injected into the normal postnatal brain, no changes were observed in glial activation, demyelination, recruitment of cytotoxic CD8 lymphocytes, or expression of IL1ß. Interestingly, when a very similar vector termed NLSCt (see Table 1) was injected into the postnatal brain after an 
excitotoxic injury, an increase in macrophage/microglia number and in the levels of IL1 $\beta$ and Cox2 enzyme were observed in the lesion (Gonzalez et al. 2011). Most interesting, the same set of studies discovered that this vector, with or without accomplished control DNA, besides inducing an inflammatory response, also induced a decrease in the brain lesion volume and in the number of degenerating neurons (Peluffo et al. 2006; Peluffo et al. 2007), an effect that was mediated by the prototypic RGD-integrin interacting motif of the vector (Peluffo et al. 2007). These data may suggest that the modulation of the inflammation by the vector may be beneficial under some circumstances. Another vector termed Tat-PTD-DRBD (see Table 1) did not induce interferon (IFN)- $\alpha$ or tumour necrosis factor (TNF)- $\alpha$ responses when incubated with primary human peripheral blood mononuclear cells (Eguchi et al. 2009). Thus, the overall data suggests that these types of vectors are less immunogenic and pro-inflammatory than most viral and other non-viral vectors.

\section{Administration routes and transgene expression}

If these types of vectors are useful for gene therapy applications is still an open question, and adequate testing of these vectors in preclinical and actual clinical studies need to be performed. In fact, it has been well established that there is no ideal vector for all gene therapy applications, being the characteristics of each vector critical for each pathological paradigm. The use of modular protein vectors is limited to pathologies accepting an acute treatment, but would be ineffective for chronic ones as the transgene expression that they determine is normally short lived. The time of transgene expression varies from a few days to more than two months, depending on the doses and the method of administration. For instance, multifunctional recombinant vectors can induce the in vivo brain expression of a reporter gene after direct injection into the bran in a model of acute brain injury, lasting the transgenic protein in the brain for 3 days (Peluffo et al. 2003), but another vector was able to determine expression in normal brain for two months after intracerebral injection (Navarro-Quiroga et al. 2002). In the case of other administration routes and pathologies, as for example the intravenous administration of these vectors, the time for transgenic protein expression in the liver may range from a few days to more that 4 months (Perales et al. 1994). In another study, the liver-selective and transient overexpression of the therapeutic protein human coagulation factor IX could be achieved using a synthetic modular glycoprotein vector, and secreted factor IX into the serum could be detected for 30 days (Ferkol et al. 1993). This same paradigm could be used for vaccination, overexpressing transiently the desired immunogenic protein (Chen and Huang 2005). Even the use of modular vectors coupled to plasmids producing shRNA show potent downregulation of an endogenous gene during 20 days when infused with osmotic pumps into the nervous system (Berhanu and Rush 2008). In all this approaches, the transient expression of a protein by means of multifunctional vectors would be desirable when compared to viral vector inoculation, which present higher risks of oncogenic and inflammatory complications, may produce very high levels of transgenic protein, and will produce the transgenic protein for life or for extended periods.

\section{Pharmacokinetics and biodistribution}

Various approaches have been undertaken to overcome the interaction of vectors with blood components to avoid aggregation as well as embolisms. Moreover for most strategies, the phagocytic clearing system of the organism must be eluded. Pharmacokinetic analysis has 
shown that physicochemical properties of the vectors such as molecular weight, electrical charge and immunogenicity (or pre-existing antibodies in the organism) are important determinants for the in vivo success of the treatment. In addition, the volume and shape of the final vector is also important as it determines if the complex will be internalized into the

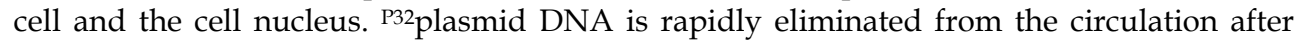
intra-venous injection in mice (Kawabata et al. 1995), mainly by a scavenger receptor mechanism-mediated uptake by hepatic phagocytes (Kawabata et al. 1995; Takakura et al. 1999). Thus, the in vivo plasmid delivery needs to modify its physicochemical properties by condensing carriers. One interesting example is the Mannose-Poly-Lysine vector (Man-PL), which was designed to accommodate plasmid DNA for the mannose receptor-mediated transfection of liver endothelial cells and Kuppfer phagocytes. After intravenous injection, the Man-PL-P32DNA vector disappeared from the plasma with a half-life of 1 minute, being $80 \%$ of the radioactivity recovered from the liver at 10 minutes (mainly in the mannose receptor+ target cells) and less than $1 \%$ at lungs or kidneys at 1 hour after (Nishikawa et al. 2000a). This vector had a size of $220 \mathrm{~nm}$ and a zeta potential of $12,1 \mathrm{mV}$, while the DNA alone had a size of $200 \mathrm{~nm}$ and a zeta potential of $-36,4$. This type of study clearly shows the importance of the condensation of plasmid DNA into small less charged particles. In accordance, it has been described that positively charged DNA complexes can activate the alternative complement pathway (Plank et al. 1996). The conjugation of vectors with hydrophilic polymers has been shown to decrease their interaction with plasmatic proteins and blood cells, increasing their half-life in circulation. One of the most used polymers is poly (ethylene glycol) (PEG). In an interesting study, Ogris and colleagues compared the blood stability of DNA/transferrin/PEI vectors with or without covalently linked PEG. The non-PEGylated vectors aggregated in plasma, bound several plasmatic proteins like IgM, fibrinogen, fibronectin, and complement C3, and also induced erythrocyte aggregation (Ogris et al. 1999). Interestingly, the PEGylated vector showed stable complex size, reduced surface charge, reduced binding of plasmatic proteins and erythrocyte aggregation, and most important, increased in vivo circulation half-life combined with enhanced transfection selectivity towards tumours.

An interesting vector for improving pharmacokinetics could be the use of natural circulating molecules, like the low-density lipoprotein (LDL). In fact it has been shown that LDL can act as a vector when mixed with plasmid DNA and injected intravenously, reaching several organs including the brain, heart, kidneys and spleen (Guevara et al.). The LDL molecule is composed of a highly hydrophobic core, surrounded by a shell of phospholipids and unesterified cholesterol, as well as a single copy of Apo B100 protein (Segrest et al. 2001). The B100 protein contains several motifs that explain the vector profile of the LDL: i) a motif that enable nucleic acid binding, ii) a motif that mediate cellular uptake, and iii) a motif that is apparently involved in transferring DNA into the cell nucleus (Guevara et al.). Interestingly, low-density particles composed of lipid, Apo B100, RNA, and core protein of hepatitis $C$ virus were reported in the plasmas of individuals infected with this virus (Andre et al. 2002). This and other studies suggested that virus might utilize the potential of the LDL particle to act as a vector as a mechanism for persistent chronic infection.

\section{Preclinical studies}

Many interesting preclinical studies have been performed with modular multifunctional protein vectors (see Table 1). The first studies showing in vivo functional effects using 
modular protein vectors were made by $\mathrm{Wu}$ and colleagues. By injecting intravenously the asialoorosomucoid glycoprotein-polylysine vector (ASOR-PL, see Table 1), they targeted hepatocytes and were able to partially and temporary correct analbuminemia and hypercholesterolemia by overexpressing human serum albumin or functional LDL receptor respectively (Wilson et al. 1992; Wu et al. 1991; Wu and $\mathrm{Wu}$ 1987). In another study, neuroprotection from an acute brain injury was achieved after direct intracerebral injection of the NLSCt vector overexpressing the antioxidant enzyme $\mathrm{Cu} / \mathrm{ZnSOD}$ (see Table 1). In this experimental setting the overexpression of the therapeutic protein could not only induce reduced infarct volume but also functional improvement of the animals (Peluffo et al. 2006). Here, the vector was injected directly into the lesioned brain by a tightly controlled microinjector, using a similar protocol reported for the injection of cells into the human Parkinsonian brain (Brundin et al.), or for the intracerebral injection of adeno-associated viral vectors for the treatment of infantile lysosomal storage disease (Worgall et al. 2008). Thus, this direct intracerebral injection approach could show some benefits in clinical cases of focal traumatic or ischemic injuries, were a delimited area is lesioned and were in some cases even a decompressing craniectomy is needed leaving a direct entrance to the brain parenchyma. Modular protein vectors have also been used for neuroprotection after acute peripheral nerve transection. For example, Barati and colleagues (Barati et al. 2006) delivered a polylysine-based polyplex targeting p75NTR positive cells accomplishing the plasmid encoding for GDNF after a peripheral nerve transection (see Table 1). They showed an almost complete reversal in neuronal death caused by GDNF transgene expression. Though this is a very interesting study, the authors performed a subtle pre-lesion to the nerve one week before the nerve transection injury to upregulate p75NTR receptor, and thus the same experiment should be repeated but under more clinically relevant conditions. In another preclinical setting, the intravenous injection (once a day during 3 consecutive days) of the RVG-9R vector accomplished to the antiviral siRNA siFvEJ (see Table 1) was able to induce $80 \%$ survival of animals 30 days after their inoculation with a fatal flavivirus (Kumar et al. 2007). Thought many modular vectors have been shown to mediate over-expression or down-regulation of reporter genes, they need to be tested in vivo in clinically relevant models for the establishment of their real potential.

\section{Conclusion}

More complex modular protein vectors including all the important domains for efficient nucleic acid delivery need to be engineered. They should include domains for DNA attachment and condensation, cell attachment and endocytosis, endosomal escape, cytosol trafficking towards the nucleus, nuclear import, and DNA release. HNRK (Domingo-Espín et al. 2011), fkAbp75-ipr (Berhanu and Rush 2008), and the fusogenic-karyophilic-NT-polyplex (Navarro-Quiroga et al. 2002) (see Table 1) are three prototypes of this increasingly complex vectors, but additional domains have to be inserted. In addition, an interesting strategy could be the exploitation of several domains that have dual functions, like poly-his with DNA attachment and endosomal escape properties, like melittin with endosomal escape properties and nuclear import potential, or histones with DNA attachment and nuclear import potential. Considering the fact that for example several cellular nuclear proteins have several nuclear localization domains, the introduction of several domains with the same function in the same vector may further increase their efficiency. In fact, dual targeting of cancer cell lines using both transferrin and RGD domains showed synergistic effects (Nie et al.). Furthermore, the 
combination of engineered modular protein vectors with engineered plasmids for long termregulated expression in vivo will be essential. For instance, the pEPI DNA vector was the first prototype of episomal vector whose function relies exclusively on chromosomal elements, replicating autonomously in low copy numbers in all cells tested (Piechaczek et al. 1999). This vector was further engineered to show regulated expression and to be removed from transduced cells when transgene expression is no longer needed (Rupprecht et al.). Finally, vectors have to be tested in vivo, but evaluating biological effects and not only reporter gene expression, and the comparison of different vectors in a same in vivo experimental setting will also contribute to the selection of the best prototypes.

\section{Acknowledgments}

This work was supported by the Comisión Sectorial de Investigación Cienctífica (CSIC) of the Universidad de la República (UDELAR) and by the Agencia Nacional de Investigación e Innovación (ANII) of the Ministerio de Cultura, Uruguay.

\section{References}

Andre, P., F. Komurian-Pradel, S. Deforges, M. Perret, J.L. Berland, M. Sodoyer, S. Pol, C. Brechot, G. Paranhos-Baccala and V. Lotteau. 2002. Characterization of low- and very-low-density hepatitis c virus rna-containing particles. J Virol 76, no. 14: 691928.

Andreu, A., N. Fairweather and A.D. Miller. 2008. Clostridium neurotoxin fragments as potential targeting moieties for liposomal gene delivery to the cns. Chembiochem 9 , no. 2: 219-31.

Arango-Rodriguez, M.L., I. Navarro-Quiroga, J.A. Gonzalez-Barrios, D.B. MartinezArguelles, M.J. Bannon, J. Kouri, P. Forgez, W. Rostene, R. Garcia-Villegas, I. Jimenez and D. Martinez-Fong. 2006. Biophysical characteristics of neurotensin polyplex for in vitro and in vivo gene transfection. Biochim Biophys Acta 1760, no. 7: 1009-20.

Aris, A., J.X. Feliu, A. Knight, C. Coutelle and A. Villaverde. 2000. Exploiting viral celltargeting abilities in a single polypeptide, non-infectious, recombinant vehicle for integrin-mediated DNA delivery and gene expression. Biotechnol Bioeng 68, no. 6: 689-96.

Aris, A. and A. Villaverde. 2003. Engineering nuclear localization signals in modular protein vehicles for gene therapy. Biochem Biophys Res Commun 304, no. 4: 625-31.

Aris, A. and A. Villaverde. 2004. Modular protein engineering for non-viral gene therapy. Trends Biotechnol 22, no. 7: 371-7.

Barati, S., P.R. Hurtado, S.H. Zhang, R. Tinsley, I.A. Ferguson and R.A. Rush. 2006. Gdnf gene delivery via the p75(ntr) receptor rescues injured motor neurons. Exp Neurol 202, no. 1: 179-88.

Barrett, L.B., M. Berry, W.B. Ying, M.N. Hodgkin, L.W. Seymour, A.M. Gonzalez, M.L. Read, A. Baird and A. Logan. 2004. Ctb targeted non-viral cdna delivery enhances transgene expression in neurons. J Gene Med 6, no. 4: 429-38.

Berhanu, D.A. and R.A. Rush. 2008. Targeted silencing of trka expression in rat forebrain neurons via the p75 receptor. Neuroscience 153, no. 4: 1115-25.

Bloomfield, V.A. 1996. DNA condensation. Curr Opin Struct Biol 6, no. 3: 334-41. 
Bonavia, R., A. Bajetto, S. Barbero, A. Albini, D.M. Noonan and G. Schettini. 2001. Hiv-1 tat causes apoptotic death and calcium homeostasis alterations in rat neurons. Biochem Biophys Res Commun 288, no. 2: 301-8.

Box, M., D.A. Parks, A. Knight, C. Hale, P.S. Fishman and N.F. Fairweather. 2003. A multidomain protein system based on the hc fragment of tetanus toxin for targeting DNA to neuronal cells. J Drug Target 11, no. 6: 333-43.

Brundin, P., R.A. Barker and M. Parmar. Neural grafting in parkinson's disease problems and possibilities. Prog Brain Res 184: 265-94.

Buschle, M., M. Cotten, H. Kirlappos, K. Mechtler, G. Schaffner, W. Zauner, M.L. Birnstiel and E. Wagner. 1995. Receptor-mediated gene transfer into human tymphocytes via binding of DNA/cd3 antibody particles to the $\mathrm{cd} 3 \mathrm{t}$ cell receptor complex. Hum Gene Ther 6, no. 6: 753-61.

Cardozo, A.K., V. Buchillier, M. Mathieu, J. Chen, F. Ortis, L. Ladriere, N. Allaman-Pillet, O. Poirot, S. Kellenberger, J.S. Beckmann, D.L. Eizirik, C. Bonny and F. Maurer. 2007. Cell-permeable peptides induce dose- and length-dependent cytotoxic effects. Biochim Biophys Acta 1768, no. 9: 2222-34.

Chaib-Oukadour, I., C. Gil and J. Aguilera. 2004. The c-terminal domain of the heavy chain of tetanus toxin rescues cerebellar granule neurones from apoptotic death: Involvement of phosphatidylinositol 3-kinase and mitogen-activated protein kinase pathways. J Neurochem 90, no. 5: 1227-36.

Chan, C.K., T. Senden and D.A. Jans. 2000. Supramolecular structure and nuclear targeting efficiency determine the enhancement of transfection by modified polylysines. Gene Ther 7, no. 19: 1690-7.

Chen, W.C. and L. Huang. 2005. Non-viral vector as vaccine carrier. Adv Genet 54: 315-37.

Corchero, J.L. and A. Villaverde. 2009. Biomedical applications of distally controlled magnetic nanoparticles. Trends Biotechnol 27, no. 8: 468-76.

Domingo-Espín, J., E. Vazquez, J. Ganz, O. Conchillo, E. García-Fruitós, J. Cedano, U. Unzueta, V. Petegnief, N. Gonzalez-Montalbán, A.M. Planas, X. Daura, H. Peluffo, N. Ferrer-Miralles and A. Villaverde. 2011. The nanoparticulate architecture of protein-based artificial viruses is supported by protein-DNA interactions. Nanomedicine In Press.

Eguchi, A., B.R. Meade, Y.C. Chang, C.T. Fredrickson, K. Willert, N. Puri and S.F. Dowdy. 2009. Efficient sirna delivery into primary cells by a peptide transduction domaindsrna binding domain fusion protein. Nat Biotechnol 27, no. 6: 567-71.

Ferkol, T., G.L. Lindberg, J. Chen, J.C. Perales, D.R. Crawford, O.D. Ratnoff and R.W. Hanson. 1993. Regulation of the phosphoenolpyruvate carboxykinase/human factor ix gene introduced into the livers of adult rats by receptor-mediated gene transfer. Faseb J 7, no. 11: 1081-91.

Ferrer-Miralles, N., E. Vazquez and A. Villaverde. 2008. Membrane-active peptides for nonviral gene therapy: Making the safest easier. Trends Biotechnol 26, no. 5: 267-75.

Fisher, K.J. and J.M. Wilson. 1997. The transmembrane domain of diphtheria toxin improves molecular conjugate gene transfer. Biochem J 321 ( Pt 1): 49-58.

Fritz, J.D., H. Herweijer, G. Zhang and J.A. Wolff. 1996. Gene transfer into mammalian cells using histone-condensed plasmid DNA. Hum Gene Ther 7, no. 12: 1395-404.

Futaki, S., T. Suzuki, W. Ohashi, T. Yagami, S. Tanaka, K. Ueda and Y. Sugiura. 2001. Arginine-rich peptides. An abundant source of membrane-permeable peptides 
having potential as carriers for intracellular protein delivery. J Biol Chem 276, no. 8: 5836-40.

Gonzalez, P., H. Peluffo, L. Acarin, A. Villaverde, B. Gonzalez and B. Castellano. 2011. Il-10 overexpression does not synergize with the neuroprotective action of rgdcontaining vectors after postnatal brain excitotoxicity, but modulates the main inflammatory cell responses. . Under second revision in the Journal of Neuroscience Research.

Gonzalez-Barrios, J.A., M. Lindahl, M.J. Bannon, V. Anaya-Martinez, G. Flores, I. NavarroQuiroga, L.E. Trudeau, J. Aceves, D.B. Martinez-Arguelles, R. Garcia-Villegas, I. Jimenez, J. Segovia and D. Martinez-Fong. 2006. Neurotensin polyplex as an efficient carrier for delivering the human gdnf gene into nigral dopamine neurons of hemiparkinsonian rats. Mol Ther 14, no. 6: 857-65.

Gottschalk, S., J.T. Sparrow, J. Hauer, M.P. Mims, F.E. Leland, S.L. Woo and L.C. Smith. 1996. A novel DNA-peptide complex for efficient gene transfer and expression in mammalian cells. Gene Ther 3, no. 5: 448-57.

Guevara, J., Jr., N. Prashad, B. Ermolinsky, J.W. Gaubatz, D. Kang, A.E. Schwarzbach, D.S. Loose and N.V. Guevara. 2010. Apo b100 similarities to viral proteins suggest basis for ldl-DNA binding and transfection capacity. J Lipid Res 51, no. 7: 1704-18.

Gump, J.M. and S.F. Dowdy. 2007. Tat transduction: The molecular mechanism and therapeutic prospects. Trends Mol Med 13, no. 10: 443-8.

Kawabata, K., Y. Takakura and M. Hashida. 1995. The fate of plasmid DNA after intravenous injection in mice: Involvement of scavenger receptors in its hepatic uptake. Pharm Res 12, no. 6: 825-30.

Kim, H.H., W.S. Lee, J.M. Yang and S. Shin. 2003. Basic peptide system for efficient delivery of foreign genes. Biochim Biophys Acta 1640, no. 2-3: 129-36.

Knight, A., J. Carvajal, H. Schneider, C. Coutelle, S. Chamberlain and N. Fairweather. 1999. Non-viral neuronal gene delivery mediated by the he fragment of tetanus toxin. Eur J Biochem 259, no. 3: 762-9.

Krishnamoorthy, G., B. Roques, J.L. Darlix and Y. Mely. 2003. DNA condensation by the nucleocapsid protein of hiv-1: A mechanism ensuring DNA protection. Nucleic Acids Res 31, no. 18: 5425-32.

Kumar, P., H. Wu, J.L. Mcbride, K.E. Jung, M.H. Kim, B.L. Davidson, S.K. Lee, P. Shankar and N. Manjunath. 2007. Transvascular delivery of small interfering rna to the central nervous system. Nature 448, no. 7149: 39-43.

Lalli, G. and G. Schiavo. 2002. Analysis of retrograde transport in motor neurons reveals common endocytic carriers for tetanus toxin and neurotrophin receptor p75ntr. J Cell Biol 156, no. 2: 233-9.

Liu, G., D. Li, M.K. Pasumarthy, T.H. Kowalczyk, C.R. Gedeon, S.L. Hyatt, J.M. Payne, T.J. Miller, P. Brunovskis, T.L. Fink, O. Muhammad, R.C. Moen, R.W. Hanson and M.J. Cooper. 2003. Nanoparticles of compacted DNA transfect postmitotic cells. J Biol Chem 278, no. 35: 32578-86.

Ma, N., S.S. Wu, Y.X. Ma, X. Wang, J. Zeng, G. Tong, Y. Huang and S. Wang. 2004. Nerve growth factor receptor-mediated gene transfer. Mol Ther 9, no. 2: 270-81.

Mastrobattista, E., M.A. Van Der Aa, W.E. Hennink and D.J. Crommelin. 2006. Artificial viruses: A nanotechnological approach to gene delivery. Nat Rev Drug Discov 5, no. 2: 115-21. 
Midoux, P., A. Kichler, V. Boutin, J.C. Maurizot and M. Monsigny. 1998. Membrane permeabilization and efficient gene transfer by a peptide containing several histidines. Bioconjug Chem 9, no. 2: 260-7.

Nath, A., K. Psooy, C. Martin, B. Knudsen, D.S. Magnuson, N. Haughey and J.D. Geiger. 1996. Identification of a human immunodeficiency virus type 1 tat epitope that is neuroexcitatory and neurotoxic. J Virol 70, no. 3: 1475-80.

Navarro-Quiroga, I., J. Antonio Gonzalez-Barrios, F. Barron-Moreno, V. Gonzalez-Bernal, D.B. Martinez-Arguelles and D. Martinez-Fong. 2002. Improved neurotensinvector-mediated gene transfer by the coupling of hemagglutinin ha2 fusogenic peptide and vp1 sv40 nuclear localization signal. Brain Res Mol Brain Res 105, no. 1-2: 86-97.

Nie, Y., D. Schaffert, W. Rodl, M. Ogris, E. Wagner and M. Gunther. Dual-targeted polyplexes: One step towards a synthetic virus for cancer gene therapy. J Control Release.

Nishikawa, M., S. Takemura, F. Yamashita, Y. Takakura, D.K. Meijer, M. Hashida and P.J. Swart. 2000a. Pharmacokinetics and in vivo gene transfer of plasmid DNA complexed with mannosylated poly(l-lysine) in mice. J Drug Target 8, no. 1: 29-38.

Nishikawa, M., M. Yamauchi, K. Morimoto, E. Ishida, Y. Takakura and M. Hashida. 2000b. Hepatocyte-targeted in vivo gene expression by intravenous injection of plasmid DNA complexed with synthetic multi-functional gene delivery system. Gene Ther 7, no. 7: 548-55.

Ogris, M., S. Brunner, S. Schuller, R. Kircheis and E. Wagner. 1999. Pegylated DNA/transferrin-pei complexes: Reduced interaction with blood components, extended circulation in blood and potential for systemic gene delivery. Gene Ther 6, no. 4: 595-605.

Ogris, M., R.C. Carlisle, T. Bettinger and L.W. Seymour. 2001. Melittin enables efficient vesicular escape and enhanced nuclear access of nonviral gene delivery vectors. J Biol Chem 276, no. 50: 47550-5.

Peluffo, H., L. Acarin, A. Aris, P. Gonzalez, A. Villaverde, B. Castellano and B. Gonzalez. 2006. Neuroprotection from nmda excitotoxic lesion by $\mathrm{cu} / \mathrm{zn}$ superoxide dismutase gene delivery to the postnatal rat brain by a modular protein vector. BMC Neurosci 7: 35.

Peluffo, H., A. Aris, L. Acarin, B. Gonzalez, A. Villaverde and B. Castellano. 2003. Nonviral gene delivery to the central nervous system based on a novel integrin-targeting multifunctional protein. Hum Gene Ther 14, no. 13: 1215-23.

Peluffo, H., P. González, A. Arís, L. Acarin, A. Villaverde, B. Castellano and B. González. 2007. Rgd domains neuroprotect the immature brain by a glial dependent mechanism. Ann Neurol 62: 251-56.

Perales, J.C., T. Ferkol, H. Beegen, O.D. Ratnoff and R.W. Hanson. 1994. Gene transfer in vivo: Sustained expression and regulation of genes introduced into the liver by receptor-targeted uptake. Proc Natl Acad Sci U S A 91, no. 9: 4086-90.

Piechaczek, C., C. Fetzer, A. Baiker, J. Bode and H.J. Lipps. 1999. A vector based on the sv40 origin of replication and chromosomal s/mars replicates episomally in cho cells. Nucleic Acids Res 27, no. 2: 426-8. 
Plank, C., K. Mechtler, F.C. Szoka, Jr. and E. Wagner. 1996. Activation of the complement system by synthetic DNA complexes: A potential barrier for intravenous gene delivery. Hum Gene Ther 7, no. 12: 1437-46.

Plank, C., B. Oberhauser, K. Mechtler, C. Koch and E. Wagner. 1994. The influence of endosome-disruptive peptides on gene transfer using synthetic virus-like gene transfer systems. J Biol Chem 269, no. 17: 12918-24.

Pollard, H., J.S. Remy, G. Loussouarn, S. Demolombe, J.P. Behr and D. Escande. 1998. Polyethylenimine but not cationic lipids promotes transgene delivery to the nucleus in mammalian cells. J Biol Chem 273, no. 13: 7507-11.

Pouton, C.W. 1998. Nuclear import of polypeptides, polynucleotides and supramolecular complexes. Adv Drug Deliv Rev 34, no. 1: 51-64.

Pyhtila, M.J., I. Miettola, T. Kurkela and A. Hoyhtya. 1976. Protection of deoxyribonucleic acid from nuclease action by histones. Acta Chem Scand B 30, no. 8: 797-8.

Read, M.L., S. Singh, Z. Ahmed, M. Stevenson, S.S. Briggs, D. Oupicky, L.B. Barrett, R. Spice, M. Kendall, M. Berry, J.A. Preece, A. Logan and L.W. Seymour. 2005. A versatile reducible polycation-based system for efficient delivery of a broad range of nucleic acids. Nucleic Acids Res 33, no. 9: e86.

Ritter, W., C. Plank, J. Lausier, C. Rudolph, D. Zink, D. Reinhardt and J. Rosenecker. 2003. A novel transfecting peptide comprising a tetrameric nuclear localization sequence. J Mol Med 81, no. 11: 708-17.

Ross, G.F., M.D. Bruno, M. Uyeda, K. Suzuki, K. Nagao, J.A. Whitsett and T.R. Korfhagen. 1998. Enhanced reporter gene expression in cells transfected in the presence of dmi2, an acid nuclease inhibitor. Gene Ther 5, no. 9: 1244-50.

Ross, G.F., R.E. Morris, G. Ciraolo, K. Huelsman, M. Bruno, J.A. Whitsett, J.E. Baatz and T.R. Korfhagen. 1995. Surfactant protein a-polylysine conjugates for delivery of DNA to airway cells in culture. Hum Gene Ther 6, no. 1:31-40.

Rupprecht, S., C. Hagedorn, D. Seruggia, T. Magnusson, E. Wagner, M. Ogris and H.J. Lipps. Controlled removal of a nonviral episomal vector from transfected cells. Gene 466, no. 1-2: 36-42.

Saccardo, P., A. Villaverde and N. Gonzalez-Montalban. 2009. Peptide-mediated DNA condensation for non-viral gene therapy. Biotechnol Adv 27, no. 4: 432-8.

Sato, Y., N. Yamauchi, M. Takahashi, K. Sasaki, J. Fukaura, H. Neda, S. Fujii, M. Hirayama, Y. Itoh, Y. Koshita, K. Kogawa, J. Kato, S. Sakamaki and Y. Niitsu. 2000. In vivo gene delivery to tumor cells by transferrin-streptavidin-DNA conjugate. Faseb J 14, no. 13: 2108-18.

Segrest, J.P., M.K. Jones, H. De Loof and N. Dashti. 2001. Structure of apolipoprotein b-100 in low density lipoproteins. J Lipid Res 42, no. 9: 1346-67.

Song, E., P. Zhu, S.K. Lee, D. Chowdhury, S. Kussman, D.M. Dykxhoorn, Y. Feng, D. Palliser, D.B. Weiner, P. Shankar, W.A. Marasco and J. Lieberman. 2005. Antibody mediated in vivo delivery of small interfering rnas via cell-surface receptors. Nat Biotechnol 23, no. 6: 709-17.

Takakura, Y., T. Takagi, M. Hashiguchi, M. Nishikawa, F. Yamashita, T. Doi, T. Imanishi, H. Suzuki, T. Kodama and M. Hashida. 1999. Characterization of plasmid DNA binding and uptake by peritoneal macrophages from class a scavenger receptor knockout mice. Pharm Res 16, no. 4: 503-8. 
Thurnher, M., E. Wagner, H. Clausen, K. Mechtler, S. Rusconi, A. Dinter, M.L. Birnstiel, E.G. Berger and M. Cotten. 1994. Carbohydrate receptor-mediated gene transfer to human t leukaemic cells. Glycobiology 4, no. 4: 429-35.

Vazquez, E., M. Roldan, C. Diez-Gil, U. Unzueta, J. Domingo-Espin, J. Cedano, O. Conchillo, I. Ratera, J. Veciana, X. Daura, N. Ferrer-Miralles and A. Villaverde. Protein nanodisk assembling and intracellular trafficking powered by an arginine-rich (r9) peptide. Nanomedicine (Lond) 5, no. 2: 259-68.

Vijayanathan, V., T. Thomas and T.J. Thomas. 2002. DNA nanoparticles and development of DNA delivery vehicles for gene therapy. Biochemistry 41, no. 48: 14085-94.

Wadhwa, M.S., W.T. Collard, R.C. Adami, D.L. Mckenzie and K.G. Rice. 1997. Peptidemediated gene delivery: Influence of peptide structure on gene expression. Bioconjug Chem 8, no. 1: 81-8.

Wagner, E., C. Plank, K. Zatloukal, M. Cotten and M.L. Birnstiel. 1992. Influenza virus hemagglutinin ha-2 n-terminal fusogenic peptides augment gene transfer by transferrin-polylysine-DNA complexes: Toward a synthetic virus-like gene-transfer vehicle. Proc Natl Acad Sci U S A 89, no. 17: 7934-8.

Wagner, E., M. Zenke, M. Cotten, H. Beug and M.L. Birnstiel. 1990. Transferrin-polycation conjugates as carriers for DNA uptake into cells. Proc Natl Acad Sci U S A 87, no. 9: 3410-4.

Wilson, J.M., M. Grossman, C.H. Wu, N.R. Chowdhury, G.Y. Wu and J.R. Chowdhury. 1992. Hepatocyte-directed gene transfer in vivo leads to transient improvement of hypercholesterolemia in low density lipoprotein receptor-deficient rabbits. J Biol Chem 267, no. 2: 963-7.

Wolfert, M.A. and L.W. Seymour. 1998. Chloroquine and amphipathic peptide helices show synergistic transfection in vitro. Gene Ther 5, no. 3: 409-14.

Worgall, S., D. Sondhi, N.R. Hackett, B. Kosofsky, M.V. Kekatpure, N. Neyzi, J.P. Dyke, D. Ballon, L. Heier, B.M. Greenwald, P. Christos, M. Mazumdar, M.M. Souweidane, M.G. Kaplitt and R.G. Crystal. 2008. Treatment of late infantile neuronal ceroid lipofuscinosis by cns administration of a serotype 2 adeno-associated virus expressing cln2 cdna. Hum Gene Ther 19, no. 5: 463-74.

Wu, G.Y., J.M. Wilson, F. Shalaby, M. Grossman, D.A. Shafritz and C.H. Wu. 1991. Receptormediated gene delivery in vivo. Partial correction of genetic analbuminemia in nagase rats. J Biol Chem 266, no. 22: 14338-42.

Wu, G.Y. and C.H. Wu. 1987. Receptor-mediated in vitro gene transformation by a soluble DNA carrier system. J Biol Chem 262, no. 10: 4429-32.

Wu, G.Y. and C.H. Wu. 1988. Receptor-mediated gene delivery and expression in vivo. J Biol Chem 263, no. 29: 14621-4.

Zauner, W., A. Kichler, W. Schmidt, K. Mechtler and E. Wagner. 1997. Glycerol and polylysine synergize in their ability to rupture vesicular membranes: A mechanism for increased transferrin-polylysine-mediated gene transfer. Exp Cell Res 232, no. 1: 137-45.

Zeng, J., H.P. Too, Y. Ma, E.S. Luo and S. Wang. 2004. A synthetic peptide containing loop 4 of nerve growth factor for targeted gene delivery. J Gene Med 6, no. 11: 1247-56.

Zeng, J. and S. Wang. 2005. Enhanced gene delivery to pc12 cells by a cationic polypeptide. Biomaterials 26, no. 6: 679-86. 
Zeng, J., X. Wang and S. Wang. 2007. Self-assembled ternary complexes of plasmid DNA, low molecular weight polyethylenimine and targeting peptide for nonviral gene delivery into neurons. Biomaterials 28, no. 7: 1443-51. 


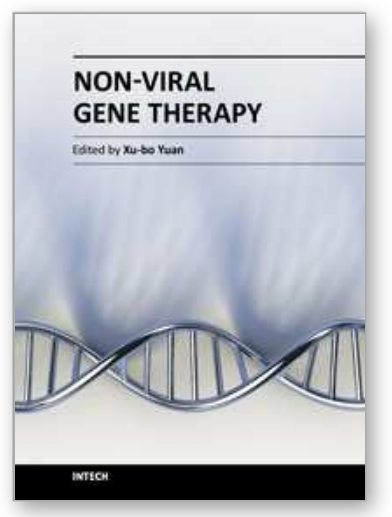

\author{
Non-Viral Gene Therapy \\ Edited by Prof. Xubo Yuan
}

ISBN 978-953-307-538-9

Hard cover, 696 pages

Publisher InTech

Published online 07, November, 2011

Published in print edition November, 2011

This book focuses on recent advancement of gene delivery systems research. With the multidisciplinary contribution in gene delivery, the book covers several aspects in the gene therapy development: various gene delivery systems, methods to enhance delivery, materials with modification and multifunction for the tumor or tissue targeting. This book will help molecular biologists gain a basic knowledge of gene delivery vehicles, while drug delivery scientist will better understand DNA, molecular biology, and DNA manipulation.

\title{
How to reference
}

In order to correctly reference this scholarly work, feel free to copy and paste the following:

Hugo Peluffo (2011). Modular Multifunctional Protein Vectors for Gene Therapy, Non-Viral Gene Therapy, Prof. Xubo Yuan (Ed.), ISBN: 978-953-307-538-9, InTech, Available from:

http://www.intechopen.com/books/non-viral-gene-therapy/modular-multifunctional-protein-vectors-for-genetherapy

\section{INTECH}

open science | open minds

\section{InTech Europe}

University Campus STeP Ri

Slavka Krautzeka 83/A

51000 Rijeka, Croatia

Phone: +385 (51) 770447

Fax: +385 (51) 686166

www.intechopen.com

\section{InTech China}

Unit 405, Office Block, Hotel Equatorial Shanghai

No.65, Yan An Road (West), Shanghai, 200040, China

中国上海市延安西路65号上海国际贵都大饭店办公楼 405 单元

Phone: +86-21-62489820

Fax: $+86-21-62489821$ 
(C) 2011 The Author(s). Licensee IntechOpen. This is an open access article distributed under the terms of the Creative Commons Attribution 3.0 License, which permits unrestricted use, distribution, and reproduction in any medium, provided the original work is properly cited. 